\title{
Circulating cell-free DNA and circulating tumor cells, the "liquid biopsies" in ovarian cancer
}

\author{
Xianliang Cheng ${ }^{1}$, Lei Zhang ${ }^{1,2}$, Yajuan Chen ${ }^{1}$ and Chen Qing ${ }^{1 *}$ (D)
}

\begin{abstract}
Limited understanding of ovarian cancer (OC) genome portrait has hindered the therapeutic advances. The serial monitoring of tumor genotypes is becoming increasingly attainable with circulating cell-free DNA (cf-DNA) and circulating tumor cells (CTCS) emerging as "liquid biopsies". They represent non-invasive biomarkers and are viable, as they can be isolated from human plasma, serum and other body fluids. Molecular characterization of circulating tumor DNA (ct-DNA) and CTCs offer unique potentials to better understand the biology of metastasis and resistance to therapies. The liquid biopsies may also give innovative insights into the process of rapid and accurate identification, resistant genetic alterations and a real time monitoring of treatment responses. In addition, liquid biopsies are shedding light on elucidating signal pathways involved in invasiveness and metastasis competence; but the detection and molecular characterization of ct-DNA and CTCS are still challenging, since they are rare, and the amount of available samples are very limited. This review will focus on the clinical potential of ct-DNA and CTCs in both the early and advanced diagnosis, prognosis, and in the identification of resistance mutations in OC.
\end{abstract}

Keywords: Ovarian cancer, Liquid biopsy, Circulating cell-free DNA, Circulating tumor DNA, Circulating tumor cell, Tumor biomarkers

\section{Background}

Ovarian cancer (OC) is the fifth most common cause of cancer death and remains the most leading cause of gynecological death [1]. These poor outcomes are directly related to the fact that a large majority, almost $75 \%$ of ovarian cancers, are diagnosed at advanced stage (III/IV), when transperitoneal, hematogeneous, and lymphatic dissemination have already occurred [2]. In general, effective therapy in OC patients can achieve $90 \%$ when the tumor is still confined to the ovary; unfortunately, only $25 \%$ of OC can be diagnosed before it exacerbates [3]. Despite the modern management, introduction of improved surgical techniques, combination chemotherapy and targeted therapies, the overall survival rates for these patients have not been significantly improved, with $70 \%$ of all OC patients succumbing to it

\footnotetext{
*Correspondence: qingchenhh@yeah.net

${ }^{1}$ School of Pharmaceutical Sciences \& Yunnan Provincial Key Laboratory of

Pharmacology for Natural Products, Kunming Medical University, 1168 West Chun Rong Road, Cheng Gong, Kunming, Yunnan 650500, People's Republic of China

Full list of author information is available at the end of the article
}

within 5 years [4]. Multiple efforts have been made to improve survival rates through early screening methods based on serum cancer antigen 125 (CA-125) concentrations and transvaginal ultrasound $[5,6]$; however, these methods have not met the standards we expected, to advocate population-based screening. Although the CA125 and transvaginal ultrasound are currently the two main techniques used to diagnose OC, they lack both sensitivity and specificity for early detection of OC. Moreover, acquired drug resistance to chemotherapies is ubiquitous during the progression of the disease. These indicate that there is an urgent need for additional cancer-specific diagnostic biomarkers to monitor tumor evolution and predict the onset of resistance to chemotherapies.

Currently, tumor biopsy samples are regularly performed in routine clinical practice with the purpose to evaluate specific biomarkers predicting therapy response [7]. However, it might be inadequate to characterize the genetic heterogeneity of tumor progression with a single 
biopsy, which does not yield comprehensive information of tumor genome.

Recently, the use of circulating cell-free DNA (cf-DNA) as a biomarker has attracted attention, due to various types of DNA alterations being reported in cf-DNA, including point mutations, microsatellite instabilities, DNA hypermethylations and loses of heterozygosity. These alterations, in many cases, were found to be identical to the ones discovered in the primary tissues from the patient, suggesting cf-DNA may be a valuable source of genetic material as a surrogate for molecular analysis in diagnosis and prognosis.

The circulating tumor cells (CTCs) analysis have also demonstrated predictive and prognostic value for both early and advanced cancer patients. Elevated CTCs in patients during the course of treatment have a significantly shorter, progression-free survival (PFS), as well as overall survival (OS). High heterogeneity has been observed by directly measuring gene expression in individual CTCs [8].

The cf-DNA and CTCs are potential surrogates for the tumor itself, offering favorable potential for serial monitoring of tumor genomes in a noninvasive approach [7]. Therefore, liquid biopsies may be feasible to improve the sensitivity and specificity, promoting earlier detection of recurrences and likelihood of cure, ensuring better diagnostics, treatment decisions and optimal management in OC.

\section{Circulating cell-free DNA}

Large quantities of tumor DNA were detected in the circulation of cf-DNA found in plasma/serum of cancer patients in 1977 [9]. Even though it has been put forward for nearly 40 years, little information is known about the release of cf-DNA in the circulation. Without question there is a percentage of cf-DNA that comes from nucleated cells [10], however, when it comes to its origin and mechanism we can only postulate. It is assumed that a rate of cf-DNA enters the plasma when the cells on the interface between the primary tumor and the circulation undergo lysis. An additional hypothesis is that both the breakdown of cancer cells and the destruction of tumor micrometastases, contribute to a portion of the release to the bloodstream [11]. The proportion of cf-DNA originating from tumor cells is not only determined by the state and size of the tumor [12], but also by clearance, degradation, lymphatic circulation, and other physiological blood processing $[12,13]$.

The cf-DNA concentration in plasma/serum of healthy subjects normally ranges from 0 to $100 \mathrm{ng}$ per $\mathrm{ml}$ of blood, with an average of $30 \mathrm{ng}$ per ml of cf-DNA [14]. In contrast, the cancer patients have concentrations from 0 and to over $1000 \mathrm{ng}$ per $\mathrm{ml}$ of blood, with an average of $180 \mathrm{ng}$ per $\mathrm{ml}$ of cf-DNA [15]. The size of
DNA fragments released from cells in cancer patients varies between 0.18 to 21 kilobases, with variations from sample to sample, in size distribution of DNA fragments [16, 17].

\section{Diagnosis}

The quantitative analysis of cf-DNA has been used as a non-invasive clinical tool for OC. Significantly elevated cf-DNA levels were detected in the serum/plasma of OC patients when compared with those of healthy individuals, and patients with benign ovarian tumors [18]. Due to the lack of suitable data, we do not know if concentrations in the plasma of $\mathrm{OC}$ patients correlate with the ovarian tumor size, stage or location.

While observing both prostate cancer and lung cancer, no correlations between plasma DNA concentration, and disease stage and histological subtypes were found [19-22]. There is also no correlation between cf-DNA concentration and age, sex, or body mass index [23]. But, the cf-DNA levels in stage III and stage IV OC, were found to be higher than those of stageland stageII OC [24].

When quantitative analyses of cf-DNA were applied for the detection of $\mathrm{OC}$, the results were not consistent and not conclusive. In a meta-analysis of 9 studies evaluating the accuracy of cf-DNA for the diagnosis of OC, the author concluded 70\% sensitivity and $90 \%$ specificity, suggesting cf-DNA had unsatisfactory sensitivity but acceptable specificity, for diagnosis of OC [25]. Therefore, cf-DNA may be used as an adjuvant diagnostic method for OC because current detection methods lack sufficient specificity such as, the detection based on serum cancer antigen 125 (CA-125), human epididymis protein4 (HE-4) and ultrasound imaging. So the potential use of cf-DNA as a combination application tool, along with the various methods used at present to diagnose OC, may be promising. Studies show that there is no correlation between the serum levels of cf-DNA and CA-125 and HE-4; and when two or three of these biomarkers were used as combined detection, specificity was improved [24].

Chromosomal instability is inherent to $\mathrm{OC}$ and is also an important hallmark [26]. The tumor-specific patterns of chromosomal instability can also be detected in cfDNA [27]. In another study, it was shown that the copy number alterations observed in cell-free DNA, match well to those in tumor biopsies of high-grade serous OC patients; and this proposed method of cell-free DNA testing outperforms both serum CA-125, and the risk of malignancy index [28]. This is a promising method when broadly applied to clinical practice for the prediction of OC. An overview of research studies on cf-DNA in OC was shown in Table 1. 
Table 1 An overview of cf-DNA in ovarian cancer patients

\begin{tabular}{|c|c|c|c|c|c|c|c|c|}
\hline cf-DNA & Year & Sample Type & NO. Patients & Targeted gene & Diagnosis & Prognosis & Response to therapy & Reference \\
\hline \multirow[t]{3}{*}{ DNA amount } & 2015 & Serum & 36 & - & $\sqrt{ }$ & - & - & [24] \\
\hline & 2014 & Plasma & 144 & Cyclophilin A & - & $\sqrt{ }$ & - & {$[30]$} \\
\hline & 2010 & Plasma & 164 & GAPDH, beta-actin & - & $\sqrt{ }$ & - & [84] \\
\hline \multirow[t]{2}{*}{ Reversion mutation } & 2017 & Plasma & 19 & BRCA1, BRCA2, TP53 & - & - & $\sqrt{ }$ & [85] \\
\hline & 2017 & Plasma & 30 & BRCA1, BRCA2, TP53 & - & - & $\sqrt{ }$ & {$[86]$} \\
\hline \multirow[t]{4}{*}{ Somatic mutation } & 2014 & Plasma/serum & 1 & FGFR2-FAM76A & $\sqrt{ }$ & - & - & [87] \\
\hline & 2012 & Plasma & 15 & KRAS, PIK3CA, H1047R & $\sqrt{ }$ & $\sqrt{ }$ & - & {$[36]$} \\
\hline & 2008 & Plasma & 119 & p53 & $\sqrt{ }$ & - & - & {$[88]$} \\
\hline & 2005 & Plasma/serum & 69 & TP53 & - & $\sqrt{ }$ & - & [89] \\
\hline \multirow[t]{4}{*}{ Aberrant methylation } & 2017 & Serum & 114 & RUNX3, TFPI2, OPCML & $\sqrt{ }$ & - & - & {$[90]$} \\
\hline & 2009 & Plasma & 33 & $\begin{array}{l}\text { BRCA1, HIC1, PAX5, } \\
\text { PGR-PROX, THBS1 }\end{array}$ & $\sqrt{ }$ & - & - & [91] \\
\hline & 2005 & Plasma & 51 & RASSF1A & $\sqrt{ }$ & $\sqrt{ }$ & - & [92] \\
\hline & 2004 & Peritoneal fluids & 57 & $\begin{array}{l}\text { Panel genes including: TIMP3, } \\
\text { CDH1, APC, ESR1, BRCA1, } \\
\text { MYOD1, GSTM3, TITF1 }\end{array}$ & $\sqrt{ }$ & $\sqrt{ }$ & - & [93] \\
\hline \multirow{3}{*}{$\begin{array}{l}\text { Chromosomal } \\
\text { abnormality }\end{array}$} & 2017 & Plasma & 57 & - & $\sqrt{ }$ & - & - & [27] \\
\hline & 2002 & Serum & 38 & - & $\sqrt{ }$ & $\sqrt{ }$ & - & [94] \\
\hline & 2001 & Serum & 30 & p53 & $\sqrt{ }$ & $\sqrt{ }$ & - & [95] \\
\hline
\end{tabular}

cf-DNA; circulating cell-free DNA; $\sqrt{ }$, yes; -, not reported.

An aberrant hypermethylation was found in stage IA/ $B$ tumors and low malignant potential borderline neoplasms. In contrast, hypermethylation of the gene panel was not observed in cyst tissue, serum or peritoneal fluid DNA, in benign ovarian disease, normal ovarian tissue DNA, or in healthy age-matched women [29]. Therefore, the analysis of tumor-specific hypermethylation in serum is viable to contribute to the detection of OC.

The use of cf-DNA may help OC patients to receive adequate therapy, increased surveillance or controlled management. However, the potential use of cf-DNA as a biomarker for early diagnosis of $\mathrm{OC}$ is the most challenging future application of cf-DNA assessment and will have to overcome many obstacles. Most of the recent reports about the use of cf-DNA in OC are limited to the advanced stage or types of OC. There are also technical hurdles to overcome, such as false positive findings, standardization of plasma processing and data analysis [7].

\section{Response to therapy}

Another objective in the exploration of the use of quantification of cf-DNA technology is to follow patients over time, while observing their response to treatment. It was reported that cf-DNA could significantly discriminate between OC patients before and after chemotherapy, demonstrating that quantification of plasma DNA might develop into a new method to assess the efficacy of chemotherapy [18]. The quantification of cf-DNA also correlates with timing of recurrence.

In another study of 144 patients with epithelial OC who were treated with bevacizumab, both PFS and OS were found to be significantly shorter in patients with high levels of cf-DNA in the blood, suggesting that cfDNA could be of independent prognostic importance in patients treated with bevacizumb [30].

Detection of mutant DNA in the plasma of patients with OC could also be useful in the follow-up of postsurgical assessment. During a study of 27 OC patients, 12 cases were found to have mutations of p53 in the cancer tissue; and in 2 of those 12 cases, identical mutations were detected in the DNA of their preoperative plasma. Mutant DNA was undetected in after surgery follow-up of these two patients with p53 mutations in their plasma; however, in one case, the p53 mutation resurfaced 16 months after surgery [31], indicating the detection of mutant DNA in cf-DNA might be promising for future monitoring of the treatment efficacy.

\section{Identification of resistance mutations}

In order to avoid continuing inefficacious therapies and prevent unnecessary side-effects, it is pivotal to detect the appearance of resistance to chemotherapy and targeted agents in the duration of all phases of cancer 
management. Cisplatin, carboplatin and paclitaxel for advanced OC patients have significantly improved PFS and OS.

However, the acquired resistance to these agents has become a challenging problem to the first-line treatment. The molecular processes of epithelial to mesenchymal transition (EMT) is critical in embryonic development [32], and also contributes to cancer and metastasis [33]. In the model of drug resistant ovarian cancers, it has been found that EMT gene signatures correlate with the presence of drug resistance [34], and the gene associated with EMT may play a significant role in cisplatin resistance in OC [35]. Therefore, the detection of genetic alterations in cf-DNA may become a noninvasive approach to monitor response and resistance to treatment in real-time, and potentially guide the targeted therapy [36].

In a study analyzing plasma cf-DNA in OC patients who received the treatment cisplatin, truncating mutation in the retinoblastoma 1 tumor-suppressor (RB1) was observed to abundantly increase [37]. Loss of heterozygosity was also observed in the 13q containing the RB1 gene, when matching the metastasis biopsies obtained after treatment [38]. Intriguingly, the loss with RB1 is associated with EMT and has been linked with chemotherapy response [39].
These solid proofs suggest that exome-wide analysis of circulating cell-free tumor DNA could be an adjunct approach to detect mutations relevant to acquired drug resistance in advanced OC patients.

\section{Circulating tumor cells}

CTCs are derived from clones in primary tumor sites [40] and found extremely rare in healthy subjects [41]. They are detectable in various metastatic carcinomas and have potential to establish metastasis in different anatomical sites. Their levels are also found to correlate with therapeutic response and survival [42]. Evidence shows that EMT assists the disseminated progression of a single carcinoma cell from primary tumor sites, and enables them to adhere and develop into distant metastases [43]. In recent years, CTCs have been considered a "liquid biopsy" for all metastatic tumors. Isolation and analyzation of captured CTCs, has demonstrated to be a promising method for non-invasive diagnosis, prognosis and real-time monitoring of treatment efficacy and drug resistance. An overview of research studies on CTCs in OC was presented in Table 2.

CTCs detection methods include two categories, cell surface marker-dependent and marker independent, approaches. Epithelial cell adhesion molecule (EpCAM) is the most commonly used epithelial cell surface markers

Table 2 Detection and prognostic relevance of CTCs in ovarian cancer patients

\begin{tabular}{|c|c|c|c|c|c|c|c|c|}
\hline Year & Sample & Sample timing & NO. Patients & $\begin{array}{l}\text { Method of CTCs } \\
\text { detection }\end{array}$ & $\begin{array}{l}\text { CTCs Positive } \\
\text { Rate }\end{array}$ & Targeted antigen/gene & $\begin{array}{l}\text { Prognostic } \\
\text { Significance }\end{array}$ & Reference \\
\hline 2017 & $\mathrm{~PB}$ & Before surgery & 54 & $\begin{array}{l}\text { Biotin-doped } \\
\text { Ppydeposited } \\
\text { microfluidic device }\end{array}$ & $98.1 \%$ & $\begin{array}{l}\text { EpCAM, TROP-2, EGFR, } \\
\text { vimentin, and N-cadherin }\end{array}$ & PFS & [96] \\
\hline 2016 & PB & Before surgery & 56 & $\begin{array}{l}\text { Size-dependent } \\
\text { seperation }\end{array}$ & $58 \%$ & $\begin{array}{l}\text { Gene panel including: } \\
\text { EpCAM, MUC1, MUC16, } \\
\text { CK18, 19, ERCC1 }\end{array}$ & NR & [59] \\
\hline 2014 & PB & Before surgery & 80 & RT-PCR & $47.5 \%$ & MAGE-As & OS, PFS & [97] \\
\hline 2013 & BM & Intra-operative period & 456 & ICC & $27 \%$ & $\mathrm{~A}-45 \mathrm{~B} / \mathrm{B} 3$ & PFS & [98] \\
\hline 2011 & PB & $\begin{array}{l}\text { Before 2nd line } \\
\text { chemotherapy }\end{array}$ & 216 & CellSearch ${ }^{\circledast}$ & $14.4 \%$ & EpCAM, CK, CD45 & OS, PFS & [57] \\
\hline 2011 & PB & Before surgery & 86 & RT-PCR & $19 \%$ & EpCAM, MUC1, HER2 & OS & [99] \\
\hline 2009 & PB & Before surgery & 71 & ICC & $60.6 \%$ & EpCAM, ESA, CK & PFS & {$[54]$} \\
\hline 2009 & BM & Intra-operative period & 112 & ICC & $25 \%$ & $\mathrm{~A}-45 \mathrm{~B} / \mathrm{B} 3$ & PFS & [100] \\
\hline 2008 & PM & Before surgery & 20 & $\begin{array}{l}\text { Density gradient/flow } \\
\text { cytometry }\end{array}$ & $90 \%$ & $\begin{array}{l}\text { Folate-AlexaFluor } 488 \\
\text { DUPA-FITC }\end{array}$ & NS & [101] \\
\hline 2007 & $\mathrm{~PB} / \mathrm{BM}$ & $\begin{array}{l}\text { Before and after } \\
\text { chemotherapy. }\end{array}$ & $57(\mathrm{~PB}) / 46(\mathrm{BM})$ & ICC & $21 \% / 54 \%$ & A-45B/B3, CK8, 18, 19 & OS, PFS & [102] \\
\hline 2006 & $\mathrm{~PB}$ & $\begin{array}{l}\text { Before and after } \\
\text { surgery }\end{array}$ & 24 & $\begin{array}{l}\text { Immunomagnetic } \\
\text { beads/RT-PCR }\end{array}$ & $75 \%$ & BER-EP4 & NS & [103] \\
\hline 2003 & PB & Before surgery & 64 & ICC & $18.7 \%$ & CK7, 8, 18, 20, EGFR & NS & [104] \\
\hline 2002 & $\mathrm{~PB} / \mathrm{BM}$ & $\begin{array}{l}\text { After surgery and } \\
\text { before adjuvant } \\
\text { chemotherapy }\end{array}$ & $90(\mathrm{~PB}) / 73(\mathrm{BM})$ & Immunomagnetic beads & $12 \% / / 21 \%$ & MOC-31 & NS & {$[105]$} \\
\hline
\end{tabular}

PB, peripheral blood; BM, bone marrow; NR, not reported; NS, not significance; OS, overall survival; PFS, progression-free survival; RT-PCR, Reverse transcriptionpolymerase chain reaction; CK, cytokeratin; ICC, immunocytochemistry. 
but is absent from normal leukocytes [44]. The CellSearch (Veridex) system utilizes ferrofluids loaded with an EpCAM antibody to capture CTCs, staining positive for cytokeratins and negative for CD45 [41], and is currently the only U.S. Food and Drug Administrationapproved technology for enumeration and detection of CTCs. However, the levels of CTCs which have hindered detection and molecular characterization [45], are extremely low in circulation with an estimated range from one in 100 million to one in a billion normal blood cells in advanced cancer patients [44, 46]. The use of CellSearch so far has also been limited to certain types of cancer, including metastasis breast cancer [47], colorectal cancer [48], and prostate cancer [49]. While using the CellSearch method, the enumerated CTCs of OC patients do not significantly correlate with clinical characteristics or patient outcomes [50]. By contrast, marker independent approaches of isolating CTCs are not limited by the expression of specific cell surface markers, but are involved in biophysical properties of CTCs, such as size [51], deformability [52], or dielectric susceptibility [53]. Some efforts with remarkable results have been achieved and seem to be promising. However, there continues to be an unmet need of methods to evaluate the role of CTCs as biomarkers in OC.

\section{Diagnosis}

In a group of 118 patients diagnosed with OC, CTCs were successfully isolated in 77 patients $(65.2 \%)$, capturing cells which may assist proliferation potential in different histology OC subtypes [3]. In another group of 71 patients undergoing evaluation for ovarian malignancy, the role of CTCs counts was explored to assess the disease stage. They found that $43(60.6 \%)$ patients had detectable CTCs, including $0 / 5$ benign patients, $1 / 10(10 \%)$ early stage, 39/52 (73.1\%) late stage, and 3/4 (75\%) unstaged patients [54]. Unfortunately, the concentration of CTCs presented in OC are extremely low, $1 / 10^{9}$ blood cells or $1 / 10^{6}$ nucleated blood cells [2], and CTCs counts are not significantly associated with clinical characteristics or patient outcomes [50]. However, the presence of CTCs at diagnosis seems to be correlated with adverse clinicopathological features, and worse clinical outcome, in OC individuals [55] with elevated CA-125 and HE-4 levels [56]. The increased numbers of CTCs also yield an unfavorable prognosis for PFS and OS in OC patients [57]. Its implementation as a valuable diagnostic tool in OC clinical settings, requires uniform methodology and prospective validation. Growing evidence also hints that monitoring CTC-positive individuals may provide an early diagnosis of OC patients. The CTCs could be detected in $24.5 \%$ of the baseline, and $20.4 \%$ of the followup samples in which two thirds identified overexpression of the cyclophilin C gene (PPIC) [56]. A panel of six genes (CCNE2, DKFZp762E1312, EMP2, MAL2, PPIC and SLC6A8) were over-expressed in cancer cell lines and were absent in healthy women. By using this panel, $44 \%$ of the cervical cancer patients, $64 \%$ of the endometrial cancer patients, and 19\% of the OC patients were identified [58]. Interestingly, another study using the MetaCell approach to detect CTCs through vital fluorescene microscopy-based cytomorphologic evaluation in combination with relative gene expression analysis, confirmed a significant expression difference of the KRT7, WT1, EPCAM, MUC16, MUC1, KRT18 and KRT19 genes [59]. Therefore, these genes could be potential biomarkers in assisting early detection and also be predictive of treatment response in gynecological malignancies. However, it is crucial to develop more specific and sensitive technologies that will contribute to early detection of OC.

\section{Identification of resistance mutation}

CTCs not only correlate with advanced stages of OC patients, but also correlate with treatment responses. One of the most interesting applications of CTCs isolation in $\mathrm{OC}$, is the opportunity to detect and monitor the active mutations related to drug resistance. It is widely known that the classical marker EpCAM, for epithelial cells, was found markedly low with only $8 \%$ of baseline and $4 \%$ of follow-up in CTCs positive samples [56]; indicating it might not be the preferable choice for the isolation or detection of CTCs [60-62]. In contrast, the PPIC in CTCs positive groups was exceedingly over-expressed in baseline groups with $68 \%$, and in follow-up groups with 69\% [56]. PPIC gene is identified as a CTC marker [58] belonging to the cyclopilins that have peptidyl-prolyl cistrans isomerase (PPIase), and are considered intracellular receptors for immunosuppressive drug cyclosporine A (PPIA) [63]. PPIA has also been shown to have significant potential for reversal of platinum chemoresistance [64] and found to be up-regulated in various human cancers with a strong correlation to malignant transformation in several types of cancers [65]. Research has also confirmed that the presence of PPIC positive CTCs, are more likely to be found in platinum resistance samples of follow-up groups, than in platinum sensitive groups [56].

Additionally, another group of genes correlating to chemoresistance was tested (MRP1-10, MDR1, ERCC1, RRM1, RRM2) [59], found to be a promising target for the therapy of chemoresistant epithelial OC patients.

\section{The added value of cf-DNA and CTCs in the diagnosis of $O C$}

CA-125 is still the main single marker in the diagnostic test of epithelial ovarian cancer (EOC), with its applications for therapeutic efficacy evaluation and monitoring 
disease status among OC patients [66, 67]. However, CA-125 also increases in benign tumors and in conditions such as endometriosis, follicular cysts, pregnancy and infection [68]. It has limited capacity for diagnostic purpose and classification of ovarian masses as benign or malignant. Ultimately, the diagnosis of specificity of this method based on CA-125 alone is not ideal.

HE4 has emerged as a new diagnostic biomarker for $\mathrm{OC}$ and may become as important as CA-125 in OC diagnosis and monitoring of treatment efficacy. HE4 is an $\mathrm{N}$-glycosylated protein encoded by a gene located in chromosome 20q12-13.1. HE4 was found in benign gynecological diseases such as ovarian cyst, uterine fibroids, endometriosis, endometrial polyps and other OCs, including endometrial and cervical cancer, but the expression levels between gynecological diseases and OC are significantly different [69]. Furthermore, HE4 has shown higher sensitivity and specificity than that of CA125 [70]. The combined analysis of CA-125 and HE4 improves the diagnostic accuracy of OC [71]. Thus, the measurement of serum HE4 can be used for the differential diagnosis between benign gynecologic diseases and $\mathrm{OC}$ [72].

CA-125 together with risk of malignancy index values (RMI) were used to construct receiver-operating characteristics (ROC) curve, as compared with cf-DNA testing. The area under the curve (AUC) was assessed, it exhibited that chromosomal instability in cf-DNA testing improved malignancy detection (AUC 0.89), outweighing serum CA-125 (AUC 0.78) as well as the RMI (AUC 0.81). Values of AUC in cf-DNA testing even further increased for high-grade serous cancers specifically (AUC 0.94). Sensitivity of cf-DNA testing was 2 to 5 -fold higher compared to CA-125 and RMI testing, by a specificity criteria of $99.6 \%$, the theoretical threshold required for OC screening [27]. The International Ovarian Tumor Analysis Group, IOTA, has initiated promising research to exploit the integration of cf-DNA testing in their prediction models (amendment to IOTA-5 study, NCT01698632) [73]. Thus, cf-DNA testing may be implemented as an important strategy for the detection of $\mathrm{OC}$, due to the potential of improved specificity in combination with well established methods [74].

The detection of CTCs is often hampered by the large number of white blood cells [75] and heterogeneity of primary tumor [76]. No specific marker is uniformly expressed by all cancer types [77], and EpCAM is not an ideal biomarker for CTCs detection as the variation of its gene expression [78]. It is most desirable to develop more specific and sensitive detection methods that will contribute to early detection of OC.

No correlation was observed between the change in CTCs and CA-125 [50], but some patients were negative in CA-125 expression and positive in CTCs. Therefore,
CTCs may provide additional prognostic information independently on CA-125. Furthermore the presence of CTCs is significantly associated with shorter OS and PFS [79]. CTCs have exhibited a prognostic value in many types of cancers and shown to be a better monitoring tool in OC than CA-125 [79]. CTCs may become an increasingly valuable tool for the detection of $\mathrm{OC}$, especially in the early stage.

Tumor biopsies are most often obtained in the process of operation. It is difficult and unsafe to take another tumor sample post operation. The molecular characterization of cf-DNA and CTCs can be detected directly in a noninvasive manner in the plasma/serum of cancer patients. Because there is no requirement for enrichment, cf-DNA is easier to obtain compared with CTCs, and the detected gene panels in cf-DNA can be used to monitor treatment response [80]. In contrast, the analysis of CTCs enable the detection of multiple mutations within single cell, which contributes to the understanding of tumor heterogeneity, disease evolution and clinical management [81]. Thus, the assessment of cf-DNA and CTCs mutational profiling could be a substitute source of tumor tissue, providing a combined transcriptome and genome information [82]. It can contribute a better chemotherapy strategy by comparing the alteration frequencies in primary tumors with the increase mutation burden in transcriptome sequencing [83]. Therefore, detecting multiple changes of gene expression from cf-DNA and CTCs can guide its specific targeted therapy and avoid harmful treatment. However, the application of cf-DNA and CTCs into routine clinic still needs more patient data.

\section{Conclusions}

The constant development and discovery of new molecular biomarkers are first and foremost to advance the treatment of OC patients. The emerging of liquid biopsies may represent a turning point in the OC management and could be a novel approach complementing traditional biopsy sampling. The main advantage of liquid biopsy analysis is based on the unique potential of cf-DNA and CTCs to offer minimally invasive samples in a convenient manner and is easily obtainable at multiple time points over the course of disease progression. Evaluation of cf-DNA and CTCs mutational profiling may provide valuable information to early assessment of treatment efficacy in real-time and may enable identification of predictive targets for early diagnosis in OC individuals. Many patients treated with matched targeted therapies develop drug resistance, therefore, it is critical to detect the molecular changes involved in drug resistance. Further research on the molecular characterization of cf-DNA and CTCs will provide a better understanding of the development of resistance to therapies, avoiding repeat biopsies and establishing more personalized 
treatment with less cost and fewer side effects for OC patients. Liquid biopsy is currently being integrated into preclinical and clinical trials and holds great promise for future genetic studies by providing an evaluation of genomic evolution associated with treatment response and resistance. The application of cfDNA and CTCs molecular characterization enhances the prediction of response to targeted therapeutics, the identification of subpopulations/gene signatures of cf-DNA and CTCs allowing for patient diagnosis, therapy stratification, accurate prognosis, and a thorough evaluation of patients for clinical trial eligibility. Even though many details remain to be addressed such as, more effective technologies with lower cost, comparisons with other emerging liquid biomarkers, and standardization of assays in evaluating cf-DNA and CTCs, this emerging field of study may bring hope to early detection and monitoring of drug resistance to OC.

\section{Abbreviations}

BM: Bone marrow; CA-125: Serum cancer antigen 125; cf-DNA: Circulating cell-free DNA; CK: Cytokeratin; CTC: Circulating tumor cell; EMT: Epithelial to mesenchymal transition; EpCAM: Epithelial cell adhesion molecule; HE4: Human epididymis protein4; ICC: Immunocytochemistry; NR: Not reported; NS: Not significance; OC: Ovarian cancer; OS: Overall survival; PB: Peripheral blood; PFS: Progression-free survival; PPIA: Immunosuppressive drug cyclosporine A; PPlase: Peptidyl-prolyl cis-trans isomerase; PPIC: Cyclophilin C gene; RB1: Retinoblastoma 1 tumor-suppressor; RT-PCR: Reverse transcriptionpolymerase chain reaction

\section{Acknowledgements}

Not applicable

\section{Funding}

This work was supported by grant from Ding Jian Academician Workstation and Collaborative Innovation Center for Natural Products and Biological Drugs of Yunnan of China.

\section{Availability of data and materials}

All data generated or analysed during this study are included in this published article.

\section{Authors' contributions}

$C Q$ and $X C$ designed and conceived of the review and contributed critical reading of the manuscript and editing. $X C$ and $L Z$ participated in drafting the manuscript and performed literature review. YC reviewed the design and critically reviewed the manuscript. All authors read and approved the final manuscript.

\section{Ethics approval and consent to participate}

Not applicable

\section{Consent for publication}

All authors agree to the submission of this article for publication.

\section{Competing interests}

The authors declare that they have no competing interests.

\section{Publisher's Note}

Springer Nature remains neutral with regard to jurisdictional claims in published maps and institutional affiliations.

\section{Author details}

${ }^{1}$ School of Pharmaceutical Sciences \& Yunnan Provincial Key Laboratory of Pharmacology for Natural Products, Kunming Medical University, 1168 West Chun Rong Road, Cheng Gong, Kunming, Yunnan 650500, People's Republic of China. ${ }^{2}$ Department of Gynecologic Oncology, The Third Affiliated Hospital of Kunming Medical University, Kunming, Yunnan, People's Republic of China.

Received: 12 August 2017 Accepted: 24 October 2017

Published online: 13 November 2017

\section{References}

1. Torre LA, Bray F, Siegel RL, Ferlay J, Lortet-Tieulent J, Jemal A. Global cancer statistics, 2012. CA Cancer J Clin. 2015;65(2):87-108.

2. Gasparri ML, Savone D, Besharat RA, Faroogi AA, Bellati F, Ruscito I, et al. Circulating tumor cells as trigger to hematogenous spreads and potential biomarkers to predict the prognosis in ovarian cancer. Tumour biology : the journal of the International Society for Oncodevelopmental Biology and Medicine. 2016;37(1):71-5.

3. Kolostova K, Matkowski R, Jedryka M, Soter K, Cegan M, Pinkas M, et al. The added value of circulating tumor cells examination in ovarian cancer staging. Am J Cancer Res. 2015;5(11):3363-75.

4. Schmalfeldt B, Kuhn W, Reuning U, Pache L, Dettmar P, Schmitt M, et al. Primary tumor and metastasis in ovarian cancer differ in their content of urokinase-type plasminogen activator, its receptor, and inhibitors types 1 and 2. Cancer Res. 1995;55(18):3958-63.

5. Buys SS, Partridge E, Black A, Johnson CC, Lamerato L, Isaacs C, et al. Effect of screening on ovarian cancer mortality: the prostate, lung, colorectal and ovarian (PLCO) cancer screening randomized controlled trial. JAMA. 2011; 305(22):2295-303.

6. Jacobs IJ, Menon U, Ryan A, Gentry-Maharaj A, Burnell M, Kalsi JK, et al. Ovarian cancer screening and mortality in the UK collaborative trial of ovarian cancer screening (UKCTOCS): a randomised controlled trial. Lancet. 2016;387(10022):945-56.

7. Esposito A, Criscitiello C, Locatelli M, Milano M, Curigliano G. Liquid biopsies for solid tumors: understanding tumor heterogeneity and real time monitoring of early resistance to targeted therapies. Pharmacol Ther. 2016; 157:120-4.

8. Powell AA, Talasaz AH, Zhang H, Coram MA, Reddy A, Deng G, et al. Single cell profiling of circulating tumor cells: transcriptional heterogeneity and diversity from breast cancer cell lines. PLoS One. 2012;7(5):e33788.

9. Leon SA, Shapiro B, Sklaroff DM, Yaros MJ, Free DNA. In the serum of cancer patients and the effect of therapy. Cancer Res. 1977;37(3):646-50.

10. Stroun M, Maurice P, Vasioukhin V, Lyautey J, Lederrey C, Lefort F, et al. The origin and mechanism of circulating DNA. Ann N Y Acad Sci. 2000;906:161-8.

11. Stroun M, Lyautey J, Lederrey C, Olson-Sand A, Anker P. About the possible origin and mechanism of circulating DNA apoptosis and active DNA release. Clinica chimica acta; international journal of clinical chemistry. 2001;313(1-2): 139-42.

12. Schwarzenbach H, Hoon DS, Pantel K. Cell-free nucleic acids as biomarkers in cancer patients. Nat Rev Cancer. 2011;11(6):426-37.

13. Gormally $E$, Caboux $E$, Vineis $P$, Hainaut $P$. Circulating free $D N A$ in plasma or serum as biomarker of carcinogenesis: practical aspects and biological significance. Mutat Res. 2007;635(2-3):105-17.

14. Fleischhacker M, Schmidt B. Circulating nucleic acids (CNAs) and cancer-a survey. Biochim Biophys Acta. 2007;1775(1):181-232.

15. Shapiro B, Chakrabarty M, Cohn EM, Leon SA. Determination of circulating DNA levels in patients with benign or malignant gastrointestinal disease. Cancer. 1983;51(11):2116-20.

16. Jahr S, Hentze H, Englisch S, Hardt D, Fackelmayer FO, Hesch RD, et al. DNA fragments in the blood plasma of cancer patients: quantitations and evidence for their origin from apoptotic and necrotic cells. Cancer Res. 2001;61(4):1659-65.

17. Stroun $M$, Anker $P$, Lyautey J, Lederrey $C$, Maurice PA. Isolation and characterization of DNA from the plasma of cancer patients. European journal of cancer \& clinical oncology. 1987;23(6):707-12.

18. Capizzi E, Gabusi E, Grigioni AD, De laco P, Rosati M, Zamagni C, et al. Quantification of free plasma DNA before and after chemotherapy in patients with advanced epithelial ovarian cancer. Diagnostic molecular pathology : the American journal of surgical pathology, part B. 2008; 17(1):34-8. 
19. Jung K, Stephan C, Lewandowski M, Klotzek S, Jung M, Kristiansen G, et al. Increased cell-free DNA in plasma of patients with metastatic spread in prostate cancer. Cancer Lett. 2004;205(2):173-80.

20. Newman AM, Bratman SV, To J, Wynne JF, Eclov NC, Modlin LA, et al. An ultrasensitive method for quantitating circulating tumor DNA with broad patient coverage. Nat Med. 2014;20(5):548-54.

21. Gautschi O, Bigosch C, Huegli B, Jermann M, Marx A, Chasse E, et al. Circulating deoxyribonucleic acid as prognostic marker in non-small-cell lung cancer patients undergoing chemotherapy. Journal of clinical oncology : official journal of the American Society of Clinical Oncology. 2004;22(20):4157-64

22. Sozzi G, Conte D, Mariani L, Lo Vullo S, Roz L, Lombardo C, et al. Analysis of circulating tumor DNA in plasma at diagnosis and during follow-up of lung cancer patients. Cancer Res. 2001;61(12):4675-8.

23. Beiter T, Fragasso A, Hudemann J, Niess AM, Simon P. Short-term treadmil running as a model for studying cell-free DNA kinetics in vivo. Clin Chem. 2011;57(4):633-6.

24. Shao X, He Y, Ji M, Chen X, Qi J, Shi W, et al. Quantitative analysis of cellfree DNA in ovarian cancer. Oncol Lett. 2015;10(6):3478-82.

25. Zhou Q, Li W, Leng B, Zheng W, He Z, Zuo M, et al. Circulating cell free DNA as the diagnostic marker for ovarian cancer: a systematic review and meta-analysis. PLoS One. 2016;11(6):e0155495.

26. Pikor L, Thu K, Vucic E, Lam W. The detection and implication of genome instability in cancer. Cancer Metastasis Rev. 2013;32(3-4):341-52.

27. Vanderstichele A, Busschaert P, Smeets D, Landolfo C, Van Nieuwenhuysen E, Leunen K, et al. Chromosomal instability in cell-free DNA as a highly specific biomarker for detection of ovarian cancer in women with adnexal masses. Clinical cancer research : an official journal of the American Association for Cancer Research. 2017;23(9):2223-31.

28. Vanderstichele A, Busschaert P, Smeets D, Landolfo C, Van Nieuwenhuysen E, Leunen $\mathrm{K}$, et al. Chromosomal instability in cell-free DNA as a highly specific biomarker for detection of ovarian cancer in women with adnexal masses. Clinical cancer research : an official journal of the American Association for Cancer Research. 2016;

29. Ibanez de Caceres I, Battagli C, Esteller M, Herman JG, Dulaimi E, Edelson MI, et al. Tumor cell-specific BRCA1 and RASSF1A hypermethylation in serum, plasma, and peritoneal fluid from ovarian cancer patients. Cancer Res. 2004; 64(18):6476-81.

30. Steffensen KD, Madsen CV, Andersen RF, Waldstrom M, Adimi P, Jakobsen A. Prognostic importance of cell-free DNA in chemotherapy resistant ovarian cancer treated with bevacizumab. Eur J Cancer. 2014;50(15):2611-8.

31. Otsuka J, Okuda T, Sekizawa A, Amemiya S, Saito H, Okai T, et al. Detection of p53 mutations in the plasma DNA of patients with ovarian cancer. International journal of gynecological cancer : official journal of the International Gynecological Cancer Society. 2004;14(3):459-64.

32. Hay ED. The mesenchymal cell, its role in the embryo, and the remarkable signaling mechanisms that create it. Developmental dynamics : an official publication of the American Association of Anatomists. 2005;233(3):706-20.

33. Iwatsuki M, Mimori K, Yokobori T, Ishi H, Beppu T, Nakamori S, et al. Epithelial-mesenchymal transition in cancer development and its clinical significance. Cancer Sci. 2010;101(2):293-9.

34. Helleman J, Smid M, Jansen MP, van der Burg ME, Berns EM. Pathway analysis of gene lists associated with platinum-based chemotherapy resistance in ovarian cancer: the big picture. Gynecol Oncol. 2010;117(2):170-6.

35. Haslehurst AM, Koti M, Dharsee M, Nuin P, Evans K, Geraci J, et al. EMT transcription factors snail and slug directly contribute to cisplatin resistance in ovarian cancer. BMC Cancer. 2012;12:91.

36. Perkins G, Yap TA, Pope L, Cassidy AM, Dukes JP, Riisnaes R, et al. Multipurpose utility of circulating plasma DNA testing in patients with advanced cancers. PLoS One. 2012;7(11):e47020.

37. Murtaza M, Dawson SJ, Tsui DW, Gale D, Forshew T, Piskorz AM, et al. Noninvasive analysis of acquired resistance to cancer therapy by sequencing of plasma DNA. Nature. 2013;497(7447):108-12.

38. Esposito A, Criscitiello C, Trapani D, Curigliano G. The emerging role of "liquid biopsies," circulating tumor cells, and circulating cell-free tumor DNA in lung cancer diagnosis and identification of resistance mutations. Curr Oncol Rep. 2017;19(1):1.

39. Knudsen ES, Knudsen KE. Tailoring to RB: tumour suppressor status and therapeutic response. Nat Rev Cancer. 2008;8(9):714-24.

40. Fiegl M, Kircher B, Zojer N. Correspondence re: T. Fehm et al., cytogenetic evidence that circulating epithelial cells in patients with carcinoma are malignant. Clin. Cancer res., 8: 2073-2084, 2002. Clinical cancer research : an official journal of the American Association for Cancer Research. 2003;9(3): 1224-5. author reply 6

41. Allard WJ, Matera J, Miller MC, Repollet M, Connelly MC, Rao C, et al. Tumor cells circulate in the peripheral blood of all major carcinomas but not in healthy subjects or patients with nonmalignant diseases. Clinical cancer research : an official journal of the American Association for Cancer Research. 2004;10(20):6897-904.

42. Krebs MG, Metcalf RL, Carter L, Brady G, Blackhall FH, Dive C. Molecular analysis of circulating tumour cells-biology and biomarkers. Nature reviews Clin Oncol. 2014;11(3):129-44.

43. Thiery JP. Epithelial-mesenchymal transitions in tumour progression. Nat Rev Cancer. 2002;2(6):442-54

44. Yu M, Stott S, Toner M, Maheswaran S, Haber DA. Circulating tumor cells: approaches to isolation and characterization. J Cell Biol. 2011:192(3):373-82.

45. Alix-Panabieres C, Pantel K. Circulating tumor cells: liquid biopsy of cancer. Clin Chem. 2013:59(1):110-8.

46. Nelson NJ. Circulating tumor cells: will they be clinically useful? J Natl Cancer Inst. 2010;102(3):146-8.

47. Hayes DF, Cristofanilli M, Budd GT, Ellis MJ, Stopeck A, Miller MC, et al. Circulating tumor cells at each follow-up time point during therapy of metastatic breast cancer patients predict progression-free and overall survival. Clinical cancer research : an official journal of the American Association for Cancer Research. 2006;12(14 Pt 1):4218-24.

48. Cohen SJ, Punt CJ, lannotti N, Saidman BH, Sabbath KD, Gabrail NY, et al. Relationship of circulating tumor cells to tumor response, progression-free survival, and overall survival in patients with metastatic colorectal cancer. Journal of clinical oncology : official journal of the American Society of Clinical Oncology. 2008;26(19):3213-21.

49. Danila DC, Heller G, Gignac GA, Gonzalez-Espinoza R, Anand A, Tanaka E, et al. Circulating tumor cell number and prognosis in progressive castrationresistant prostate cancer. Clinical cancer research : an official journal of the American Association for Cancer Research. 2007;13(23):7053-8.

50. Liu JF, Kindelberger D, Doyle C, Lowe A, Barry WT, Matulonis UA. Predictive value of circulating tumor cells (CTCS) in newly-diagnosed and recurrent ovarian cancer patients. Gynecol Oncol. 2013:131(2):352-6.

51. Vona G, Sabile A, Louha M, Sitruk V, Romana S, Schutze $K$, et al. Isolation by size of epithelial tumor cells : a new method for the immunomorphological and molecular characterization of circulatingtumor cells. Am J Pathol. 2000; 156(1):57-63.

52. Aghaamoo M, Zhang Z, Chen X, Xu J. Deformability-based circulating tumor cell separation with conical-shaped microfilters: concept, optimization, and design criteria. Biomicrofluidics. 2015;9(3):034106.

53. Chiu TK, Chou WP, Huang SB, Wang HM, Lin YC, Hsieh CH, et al. Application of optically-induced-dielectrophoresis in microfluidic system for purification of circulating tumour cells for gene expression analysis- cancer cell line model. Sci Rep. 2016:6:32851.

54. Fan T, Zhao Q, Chen JJ, Chen WT, Pearl ML. Clinical significance of circulating tumor cells detected by an invasion assay in peripheral blood of patients with ovarian cancer. Gynecol Oncol. 2009;112(1):185-91.

55. Romero-Laorden N, Olmos D, Fehm T, Garcia-Donas J, Diaz-Padilla I. Circulating and disseminated tumor cells in ovarian cancer: a systematic review. Gynecol Oncol. 2014;133(3):632-9.

56. Obermayr E, Castillo-Tong DC, Pils D, Speiser P, Braicu I, Van Gorp T, et al. Molecular characterization of circulating tumor cells in patients with ovarian cancer improves their prognostic significance - a study of the OVCAD consortium. Gynecol Oncol. 2013;128(1):15-21.

57. Poveda A, Kaye SB, McCormack R, Wang S, Parekh T, Ricci D, et al. Circulating tumor cells predict progression free survival and overall survival in patients with relapsed/recurrent advanced ovarian cancer. Gynecol Oncol. 2011;122(3):567-72

58. Obermayr E, Sanchez-Cabo F, Tea MK, Singer CF, Krainer M, Fischer MB, et al. Assessment of a six gene panel for the molecular detection of circulating tumor cells in the blood of female cancer patients. BMC Cancer. 2010;10: 666.

59. Kolostova K, Pinkas M, Jakabova A, Pospisilova E, Svobodova P, Spicka J, et al. Molecular characterization of circulating tumor cells in ovarian cancer. Am J Cancer Res. 2016:6(5):973-80.

60. Konigsberg R, Obermayr E, Bises G, Pfeiler G, Gneist M, Wrba F, et al. Detection of EpCAM positive and negative circulating tumor cells in metastatic breast cancer patients. Acta Oncol. 2011;50(5):700-10. 
61. Sieuwerts AM, Kraan J, Bolt J, van der Spoel P, Elstrodt F, Schutte M, et al. Antiepithelial cell adhesion molecule antibodies and the detection of circulating normal-like breast tumor cells. J Natl Cancer Inst. 2009;101(1):61-6.

62. Mikolajczyk SD, Millar LS, Tsinberg P, Coutts SM, Zomorrodi M, Pham T, et al. Detection of EpCAM-negative and cytokeratin-negative circulating tumor cells in peripheral blood. Journal of oncology. 2011;2011:252361.

63. Craescu CT, Rouviere N, Popescu A, Cerpolini E, Lebeau MC, Baulieu EE, et al. Three-dimensional structure of the immunophilin-like domain of FKBP59 in solution. Biochemistry. 1996;35(34):11045-52.

64. Sood AK, Sorosky JI, Squatrito RC, Skilling JS, Anderson B, Buller RE, Cyclosporin A. Reverses chemoresistance in patients with gynecologic malignancies. Neoplasia. 1999;1(2):118-22.

65. Lee J, Kim SS. An overview of cyclophilins in human cancers. The Journal of international medical research. 2010;38(5):1561-74.

66. Duffy MJ, Bonfrer JM, Kulpa J, Rustin GJ, Soletormos G, Torre GC, et al. CA125 in ovarian cancer: European group on tumor markers guidelines for clinical use. International journal of gynecological cancer : official journal of the International Gynecological Cancer Society. 2005;15(5):679-91.

67. Rustin GJ, Bast RC, Jr., Kelloff GJ, Barrett JC, Carter SK, Nisen PD, et al. Use of CA-125 in clinical trial evaluation of new therapeutic drugs for ovarian cancer. Clinical cancer research : an official journal of the American Association for Cancer Research. 2004;10(11):3919-3926.

68. Buamah P. Benign conditions associated with raised serum CA-125 concentration. J Surg Oncol. 2000;75(4):264-5.

69. Wei SU, Li H, Zhang B. The diagnostic value of serum HE4 and CA-125 and ROMA index in ovarian cancer. Biomedical reports. 2016;5(1):41-4.

70. Moore RG, Brown AK, Miller MC, Badgwell D, Lu Z, Allard WJ, et al. Utility of a novel serum tumor biomarker HE4 in patients with endometrioid adenocarcinoma of the uterus. Gynecol Oncol. 2008;110(2):196-201.

71. Lenhard M, Stieber P, Hertlein L, Kirschenhofer A, Furst S, Mayr D, et al. The diagnostic accuracy of two human epididymis protein 4 (HE4) testing systems in combination with CA125 in the differential diagnosis of ovarian masses. Clin Chem Lab Med. 2011;49(12):2081-8.

72. Lin J, Qin J, Sangvatanakul V. Human epididymis protein 4 for differential diagnosis between benign gynecologic disease and ovarian cancer: a systematic review and meta-analysis. Eur J Obstet Gynecol Reprod Biol. 2013;167(1):81-5.

73. Kaijser J, Bourne T, Valentin L, Sayasneh A, Van Holsbeke C, Vergote I, et al. Improving strategies for diagnosing ovarian cancer: a summary of the international ovarian tumor analysis (IOTA) studies. Ultrasound in obstetrics \& gynecology : the official journal of the International Society of Ultrasound in Obstetrics and Gynecology. 2013;41(1):9-20.

74. Gusnanto A, Tcherveniakov P, Shuweihdi F, Samman M, Rabbitts P, Wood HM. Stratifying tumour subtypes based on copy number alteration profiles using next-generation sequence data. Bioinformatics. 2015;31(16):2713-20.

75. Mostert B, Sleijfer S, Foekens JA, Gratama JW. Circulating tumor cells (CTCs): detection methods and their clinical relevance in breast cancer. Cancer Treat Rev. 2009:35(5):463-74.

76. Paterlini-Brechot $P$, Benali NL. Circulating tumor cells (CTC) detection: clinical impact and future directions. Cancer Lett. 2007;253(2):180-204.

77. Went PT, Lugli A, Meier S, Bundi M, Mirlacher M, Sauter G, et al. Frequent EpCam protein expression in human carcinomas. Hum Pathol. 2004:35(1):122-8.

78. Zhong XY, Kaul S, Eichler A, Bastert G. Evaluating GA733-2 mRNA as a marker for the detection of micrometastatic breast cancer in peripheral blood and bone marrow. Arch Gynecol Obstet. 1999;263(1-2):2-6.

79. Pearl ML, Dong H, Tulley S, Zhao Q, Golightly M, Zucker S, et al. Treatment monitoring of patients with epithelial ovarian cancer using invasive circulating tumor cells (iCTCS). Gynecol Oncol. 2015;137(2):229-38.

80. Ignatiadis M, Dawson SJ. Circulating tumor cells and circulating tumor DNA for precision medicine: dream or reality? Annals of oncology : official journal of the European society for. Med Oncol. 2014;25(12):2304-13.

81. Brouwer A, De Laere B, Peeters D, Peeters M, Salgado R, Dirix L, et al. Evaluation and consequences of heterogeneity in the circulating tumor cell compartment. Oncotarget. 2016;7(30):48625-43.

82. Klein CA, Seidl S, Petat-Dutter K, Offner S, Geigl JB, Schmidt-Kittler O, et al. Combined transcriptome and genome analysis of single micrometastatic cells. Nat Biotechnol. 2002;20(4):387-92.

83. Robinson DR, YM W, Lonigro RJ, Vats P, Cobain E, Everett J, et al. Integrative clinical genomics of metastatic cancer. Nature. 2017;548(7667):297-303.

84. Kamat AA, Baldwin M, Urbauer D, Dang D, Han LY, Godwin A, et al. Plasma cell-free DNA in ovarian cancer: an independent prognostic biomarker. Cancer. 2010;116(8):1918-25.
85. Weigelt B, Comino-Mendez I, de Bruijn I, Tian L, Meisel JL, Garcia-Murillas I, et al. Diverse BRCA1 and BRCA2 reversion mutations in circulating cell-free DNA of therapy-resistant breast or ovarian cancer. Clinical cancer research : an official journal of the American Association for Cancer Research. 2017;

86. Christie EL, Fereday S, Doig K, Pattnaik S, Dawson SJ, Bowtell DDL. Reversion of BRCA1/2 germline mutations detected in circulating tumor DNA from patients with high-grade serous ovarian cancer. Journal of clinical oncology : official journal of the American Society of Clinical Oncology. 2017;35(12):1274-80.

87. Martignetti JA, Camacho-Vanegas O, Priedigkeit N, Camacho C, Pereira E, Lin L, et al. Personalized ovarian cancer disease surveillance and detection of candidate therapeutic drug target in circulating tumor DNA. Neoplasia. 2014;16(1):97-103.

88. Shah CA, Allison KH, Garcia RL, Gray HJ, Goff BA, Swisher EM, Intratumoral T. Cells, tumor-associated macrophages, and regulatory T cells: association with p53 mutations, circulating tumor DNA and survival in women with ovarian cancer. Gynecol Oncol. 2008;109(2):215-9.

89. Swisher EM, Wollan M, Mahtani SM, Willner JB, Garcia R, Goff BA, et al. Tumor-specific p53 sequences in blood and peritoneal fluid of women with epithelial ovarian cancer. Am J Obstet Gynecol. 2005;193(3 Pt 1):662-7.

90. Wang B, Yu L, Luo X, Huang L, Li QS, Shao XS, et al. Detection of OPCML methylation, a possible epigenetic marker, from free serum circulating DNA to improve the diagnosis of early-stage ovarian epithelial cancer. Oncol Lett. 2017:14(1):217-23.

91. Melnikov A, Scholtens D, Godwin A, Levenson V. Differential methylation profile of ovarian cancer in tissues and plasma. The Journal of molecular diagnostics : JMD. 2009;11(1):60-5.

92. Ma L, Liu FR, Zhang SL. [Detection of circulating hypermethylated tumorspecific RASSF1A DNA in ovarian cancer patients]. Zhonghua bing li xue za zhi $=$ Chinese journal of pathology. 2005;34(12):785-7.

93. Muller HM, Millinger S, Fiegl H, Goebel G, Ivarsson L, Widschwendter A, et al. Analysis of methylated genes in peritoneal fluids of ovarian cancer patients: a new prognostic tool. Clin Chem. 2004;50(11):2171-3.

94. Zhang $\mathrm{H}$, Li Z, Chen M, Zhang G, Xu K. [Loss of heterozygosity at chromosome 3p14, 25 in serum DNA from ovarian cancer patients]. Zhonghua fu chan ke za zhi. 2002;37(5):298-300.

95. Numa F, Umayahara K, Suehiro Y, Hirakawa H, Nawata S, Suminami Y, et al. Serum anti-p53 antibodies in uterine and ovarian cancer: association with dna sequence copy number abnormalities. Tumour biology : The J of the Int. Soc. for Oncodevelopmental Biol. and Med. 2001;22(3):162-8.

96. Lee M, Kim EJ, Cho Y, Kim S, Chung HH, Park NH, et al. Predictive value of circulating tumor cells (CTCS) captured by microfluidic device in patients with epithelial ovarian cancer. Gynecol Oncol. 2017;145(2):361-5.

97. Sang M, Wu X, Fan X, Sang M, Zhou X, Zhou N. Multiple MAGE-A genes as surveillance marker for the detection of circulating tumor cells in patients with ovarian cancer. Biomarkers : biochemical indicators of exposure, response, and susceptibility to chemicals. 2014;19(1):34-42.

98. Fehm T, Banys M, Rack B, Janni W, Marth C, Blassl C, et al. Pooled analysis of the prognostic relevance of disseminated tumor cells in the bone marrow of patients with ovarian cancer. International journal of gynecological cancer : official journal of the International Gynecological Cancer Society. 2013;23(5):839-45

99. Aktas B, Kasimir-Bauer S, Heubner M, Kimmig R, Wimberger P. Molecular profiling and prognostic relevance of circulating tumor cells in the blood of ovarian cancer patients at primary diagnosis and after platinum-based chemotherapy. International journal of gynecological cancer : official journal of the International Gynecological Cancer Society. 2011;21(5):822-30.

100. Banys M, Solomayer EF, Becker S, Krawczyk N, Gardanis K, Staebler A, et al. Disseminated tumor cells in bone marrow may affect prognosis of patients with gynecologic malignancies. International journal of gynecological cancer: official journal of the International Gynecological Cancer Society. 2009;19(5):948-52.

101. He W, Kularatne SA, Kalli KR, Prendergast FG, Amato RJ, Klee GG, et al. Quantitation of circulating tumor cells in blood samples from ovarian and prostate cancer patients using tumor-specific fluorescent ligands. Int J Cancer. 2008;123(8):1968-73.

102. Wimberger $P$, Heubner M, Otterbach F, Fehm T, Kimmig R, Kasimir-Bauer S. Influence of platinum-based chemotherapy on disseminated tumor cells in blood and bone marrow of patients with ovarian cancer. Gynecol Oncol. 2007;107(2):331-8 
103. Oikonomopoulou K, Scorilas A, Michael IP, Grass L, Soosaipillai A, Rosen B, et al. Kallikreins as markers of disseminated tumour cells in ovarian cancera pilot study. Tumour biology : the journal of the International Society for Oncodevelopmental Biology and Medicine. 2006;27(2):104-14.

104. Judson PL, Geller MA, Bliss RL, Boente MP, Downs LS Jr, Argenta PA, et al. Preoperative detection of peripherally circulating cancer cells and its prognostic significance in ovarian cancer. Gynecol Oncol. 2003;91(2):389-94.

105. Marth C, Kisic J, Kaern J, Trope C, Fodstad O. Circulating tumor cells in the peripheral blood and bone marrow of patients with ovarian carcinoma do not predict prognosis. Cancer. 2002;94(3):707-12.

Submit your next manuscript to BioMed Central and we will help you at every step:

- We accept pre-submission inquiries

- Our selector tool helps you to find the most relevant journal

- We provide round the clock customer support

- Convenient online submission

- Thorough peer review

- Inclusion in PubMed and all major indexing services

- Maximum visibility for your research

Submit your manuscript at www.biomedcentral.com/submit
Biomed Central 